Article

\title{
Parametric design applied to Heritage Buildings. A dialogue between tradition and evolution. The case study of Saint Clare's Monastery in Belalcazar, Spain.
}

\author{
Pablo Manuel Millán-Millán ${ }^{1}$, Celia Chacón-Carretón ${ }^{2}$ and José María Cabeza Laínez ${ }^{3, *}$ \\ 1 Department of Architectural Projects, University of Seville; pmillan1@us.es \\ 2 Department of Architectural Projects, University of Seville; celiachacon.c@gmail.com \\ 3 Department of Architectural Composition, University of Seville, Av. Reina Mercedes 2, 41002 Sevilla, Spain; \\ crowley@us.es
}

\begin{abstract}
The different technical and legal tools intended for heritage protection have introduced the novel possibility of enjoying important monumental complexes. The divergence lies in the artistic contexts in which, due to the genesis of their programmatic typology, they require residential uses, as is the case of monasteries. This article collects the results of a long-span research, whose main objective has been to find a tool that could allow us to measure different indicators on a continuous basis in which both the protection of the elements, and the capacity for habitation, are safeguarded. To this aim we have set in context the research at the Monastery of Santa Clara de la Columna in Belalcázar (Córdoba), a location with the highest possible heritage protection of Spanish ranking which, in turn, accommodates a religious community. The results have allowed us to design innovative parameters for habitation, within a protected and endangered heritage context.
\end{abstract}

Keywords: BIM; heritage; conservation; sustainability; monastic spaces; religious architecture.

\section{Introduction}

From the beginning of heritage conservation' laws in Spain, they have effected overprotection of some vestiges in certain cases and disrepair of others. Such is the case of heritage crystallization [1], in which material configurations of built-up complexes and fragments of cities have been shielded, perhaps ignoring the actual reality of such heritage. In developing this material protection of movable or immovable elements, important and sophisticated procedures and tools have been created. These have resulted in profound knowledge and testing: construction phases, materials used, periods, historical sequences, etc.

With these procedures, we have been able to intervene by restoring, adding value, consolidating the most important phases of certain architectures, whilst being obliged to eliminate any element that could cause deterioration. The processes of expulsion of daily life from the protected architectures, have ensured material conservation, but have lost the wealth of uses that were offered in these spaces.

Digital modelling has been one of those tools generated for the conservation and study of heritage and historical structures. This has principally based its potential on reaching an exact three-dimensional and constructive level of precision, forgetting to explore the qualities of the architectural heritage, from a critical and contemporary perspective. HBIM (Heritage Building Information Modelling) offers the possibility to implement other factors capable of produced a more comprehensive assessment of the architectural heritage, such as the comfort of spaces.

The article collects the procedure carried out in the search for parameterizations that allow us to study heritage objectively, together with the development of its daily life. For this aim, we have taken as a reference, a monastery of great heritage value which, at present, is obliged to separate its uses, due to the impossibility of inhabiting the protected areas. (Figure 01) 
Figure 1. Aerial photo of the monastic complex, 2021. Source: Authors.

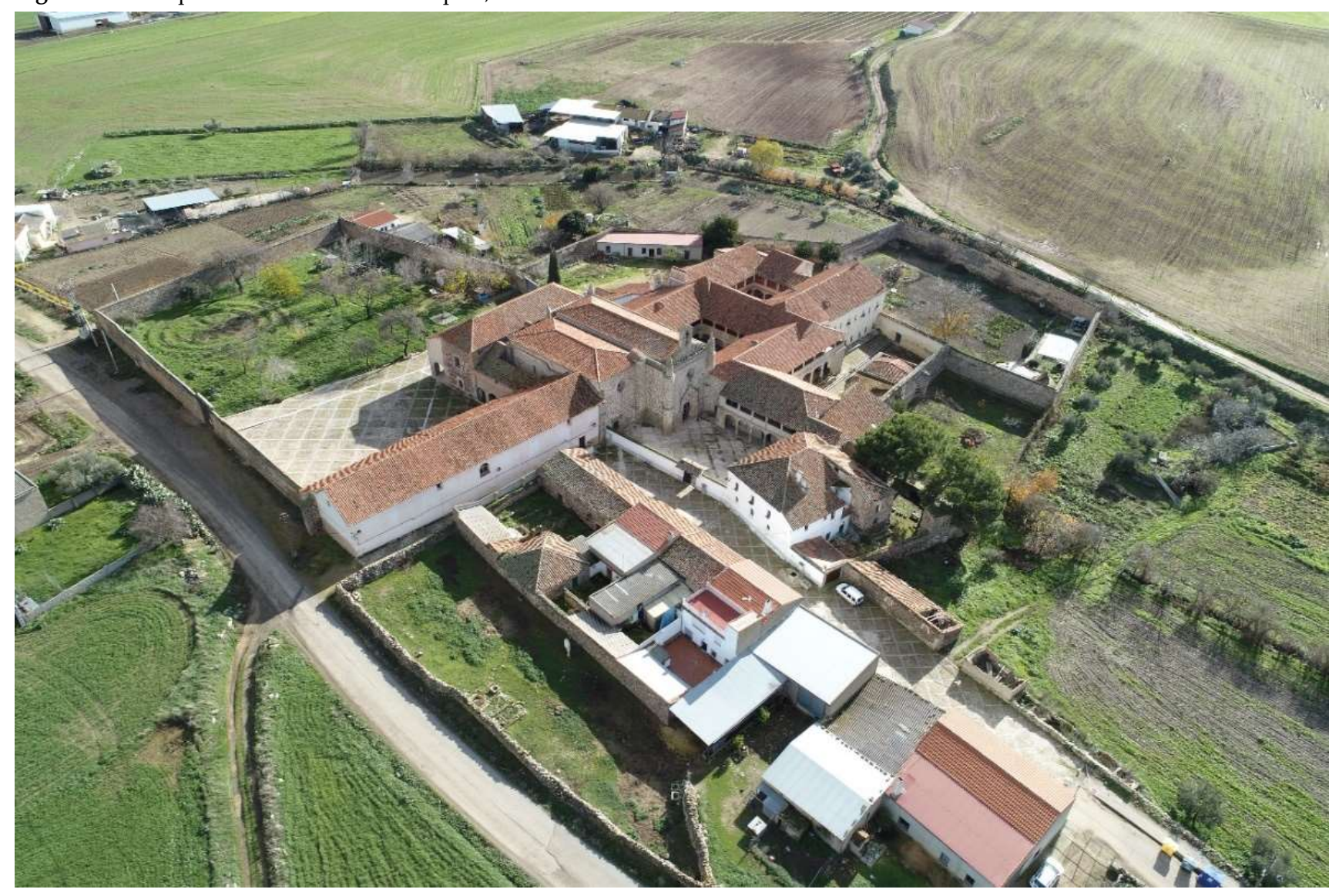

\section{Materials and Methods}

The protection of the architectural heritage implies one technical dimension, for the physical preservation of historical structures, and other social dimension, as heritage must be disseminated within society to safeguard its values and essence [2]. Today, the approach to this issue transcends the more traditional heritage framework. It belongs to a recent, and constantly evolving, research forum, with daily repercussions in areas which transcend architecture, the information age and visual culture [3].

According to the Rilievo Charter [4], in the year 2000, surveying was declared fundamental. The knowledge and digitization of the objects under study is approached from the point of view of the heritage protection project, executed by the world of graphic expression. This is where drawing induces a process that should not only be valued for its results, but instead as a tool and method, when recording notions that are developed in the transversality of facts, in this case, architectural. The multiple resources offered by graphic representation allow multiple translations between the work, in its architecture and materialization (movable or immovable) and conceived by means of the intentionality of the model, the selection of information, and the diverse and new dimensions collected from the elements studied [5].

The BIM (Building Information Modelling) tool is defined as a shared digital graphic representation system, of the physical and functional characteristics of any constructed object which constitutes a reliable basis for decision-making [6]. BIM processes are already established for new buildings, however, this is not the case in most existing buildings that are not yet maintained, renovated or deconstructed with BIM [7]. This happens despite the fact that the main use of the tool is based on the most extensive quality of integrating and organizing all the factors under a single file. The effective use allows for the definition of the architectural evolution, from the ideation phase, its development, and its execution, to the end of its life cycle. Once the 2D level are completed, the BIM stands out among 
other formats, for advancing beyond the geometric and constructive 3D, by associating extra dimensions: 4D to include temporal sequences; 5D in references to the incorporation of costs; 6D to indicate the association with certain environmental behaviors; and, 7D to finally collect the maintenance schedules (see Figure 2). The addition of qualitative and quantitative technical information on the objects included in the model, and their relationships which are established inside and outside, through links to external documents, characterize the potential of its use, according to the heritage information systems and the already collected documents [8].

The complexity that these models are able to reach, implies a demand for a terminology of their functional parts. The Level of Development (LOD) categorizes the model, according to the level of precision and reliability associated with the said BIM file. This definition is subdivided into sequences, regarding its development level: LOD100, LOD200, LOD300, LOD400 and LOD500, according to the American Institute of Architects [9]. This hierarchy, which allows graphic realities to be quickly classified, is translated to the heritage world as Level of Knowledge (LOK). This arises from the level of information that is achieved and collected in the model, from a contemporary perspective. This parallelism occurs indirectly, as the graphic accuracy is determined by the documentation and its discrimination within the survey process, according to the significant value in the protection. In the same way, the LOK depends on the information available and, later, on its reflection in the modelling, always maintaining graphic accuracy and defining gradations which, according to their ascending improvement, perpetuate the depth of the definition and the formal and historical knowledge of the property [10].

Despite the rapid evolution and BIM Standards, challenging research opportunities arise from process automation and the adaptation of BIM to the requirements of existing buildings [11]. The reason by which many buildings are not managed or maintained properly, are: lack of knowledge, experience, resources, and dependence on other stakeholders [12]. Recent research has focused on the methodology of the tool beyond the outcome. In this way, the objective is assumed as the process of understanding the survey, and therefore, the asset itself, including qualities such as the potential of the BIM system as a research, conservation activities and dissemination manager [13].

The transition between the collection of data and their BIM graphic expression, as a consequence of the digital capture process, diverges within various protocols. Photogrammetry is one of the methods that has experienced most advances, thanks to the recent appearance of dimensional data collection of surface morphology (derived from other capture systems). The 3D scanner, or the advanced photogrammetry software itself, collects colors and textures. All are based on the co-ordination between the acquisition of photographs, and their translation into geometric information through restitution or rectification [14]. The computer applications translate the clouds of points generated on surfaces in a highly faithful manner, but Angulo Fornos [15] indicated the caveat of unmanageable information, a fundamental aspect in historical structures. This is why a recurring stance is to carry out a manual treatment through classification, hierarchical organization and simplification. This procedure subsequently allows for the model to be centered on the most intrinsic and representative references, compared to the so-called semi-automatic approaches in which the whole generation prevails by virtue of algorithms. These are applied globally, always maintaining the prior reflection phase for the discretization and revision of certain aspects, compared to those obtained automatically.

Apollonio, Gaiani and Sun [16] highlight that the aspects which concern current research are those which influence the adaptation of the BIM methodology to the specific characteristics of historical architecture. This is based on the level of knowledge that can be incorporated, and the semantic structures available for historical heritage. Some authors mainly focus on the analysis of the historic building, and the generation of knowledge that a digital model should incorporate, considering geometric precision as a characteristic of the model which can evolve, according to its level of knowledge and development. They highlight the quality of the tool to allow progressive improvement, 
based on the analysis and incorporation of information, during the evolution of the architecture [17].

Consequently, it is essential to reflect on the level of detail and the simplification of models useful for conservation projects [18]. Both aspects are related to the possibility of modifying the parameters of the shape of the architectural elements, in particular, historical objects that are often irregular or isotropic. Regarding HBIM, it has been illustrated how a library of interactive parametric objects can be built, subject to the variability of the historical dimension of architectural patterns. This inclusion in the methodology provides architects, engineers, archaeologists and historians, etc., among other agents involved, with concepts and tools requiring a different and additional vision, taking into account aspects that are not normally addressed in new building projects [19].

One of the aspects of greatest interest for this research is the use of parameters when defining heritage architecture. Its quality as an information structure [20] allows direct association of information to elements, spaces, etc., and, in turn, the ability to generate tables, or repositories of internal or external information. All this includes not only the data types associated with the locations, which the BIM tool supports, but also historical planimetry, documentary files, images, URL information, etc. Through this association of data, researchers such as Castellano Román [21] gathered conclusions about the spatiality of the Cartuja de Jerez, with regard to its heritage potential, in levels of protection, state of conservation, urgency of intervention, vulnerability and accessibility for visitors.

Architecture (materials, systems, elements, spaces, complexes, images, etc.) establishes relationships between technique and society, for the creation of a human co habitability [22]. In the specific case of heritage, its enhancement and protection are additions to its architectural reality, and therefore, the interest that sparks its maintenance would be unsatisfactory if its condition of enrichment of intangible values were not ratified [23]. Today, habitability is understood on a broader scope of the quantitative and qualitative spectrum, determined by the adequacy of each of the territorial scales.

As evidenced in these approaches, the definition of habitability includes a work to determine the factors and variables which allow establishing standards of residential wellbeing, with a transverse reading criterion related to the environment and the community, or in other words, more sustainable [24]. The decisive approach to the habitability of the spaces is disregarded in heritage cases, passing to a secondary level in favor of protection, so that the qualities related to comfort and health are subordinated to conservation and protection of the property, causing divergences and contradictions, according to the requirements applied to other constructions.

The implementation of HBIM still requires a methodological debate, and practical experience, to apply this type of documentation in a broader process of conservation and the maintenance of heritage [25]. Taking these challenges into account, HBIM libraries require a broad and shared exploration of the objects, the production of data and their interpretation [26]. Finally, there is a knowledge gap in the automation and adaptation of BIM technology towards existing buildings, as studies do not always take into account social and cultural needs, which are fundamental initiatives for heritage projects [27]. 


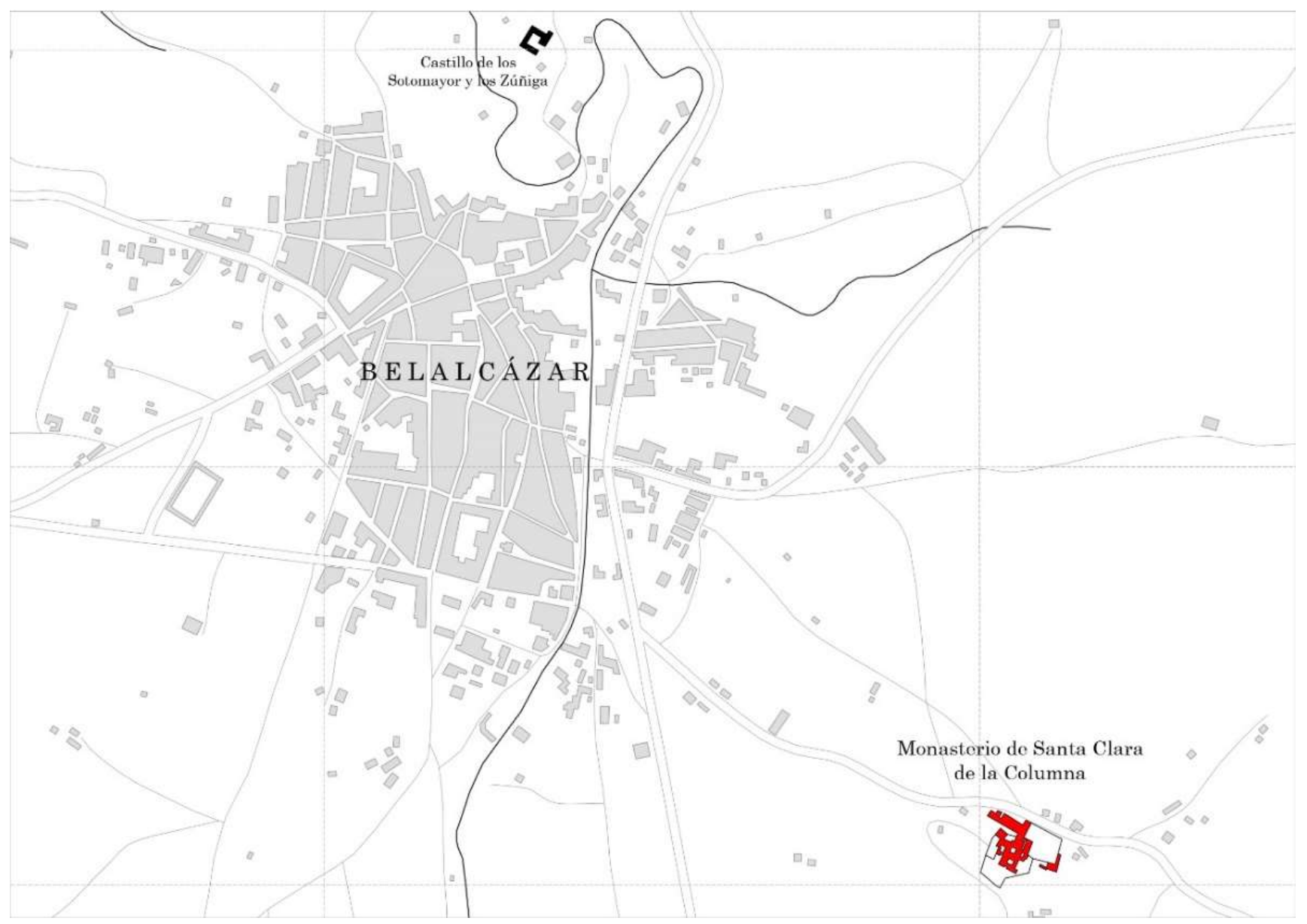

Figure 2. Location plan of the monastic complex, 2021. Source: Authors.

\section{Results}

The selection as a case study of the Monastery of Santa Clara de la Columna in Belalcázar (Córdoba) for this research is due basically to two reasons: it is a heritage complex with special needs to be inhabited but at the same time is endangered and should be protected. Both realities converge in an architecture that demands this double analysis, and serves as a field of experimentation for study, development and adjustment of this new mode of parameterization of inhabited heritage architectures.

The Monastery of Santa Clara de la Columna, declared an Asset of Cultural Interest in 1982, constitutes one of the main monastic complexes in southern Spain, and one of the fundamental pillars of the historical and artistic heritage of the Pedroches Valley. It was founded for Franciscan Friars by Elvira de Zúñiga, widow of Alfonso de Sotomayor, in 1476 [28]. After spending a short time there, two of her daughters decided to take up the habit of the Seraphic Order and begin to live in a house near the cloister. This group of women (not yet constituted as Clare nuns) began to increase, and they saw the need to erect a new place for the Friars so that they could stay in that place. It was in 1490 when the construction of the cloister of the Five Martyrs of Morocco was finished for the Friars, with the Clare sisters staying in the premises they had occupied formerly. From that moment (21 March 1490), to the present day, the monastery has been inhabited, without interruption, by the Clare Sisters. (Figure 02).

The monastic complex is located on the outskirts of Belalcázar, in the so-called Villeta de Santa Clara, an area outside the municipality, rich in large orchards and irrigated from different water sources and supply points. This is how the Chronicler of the Provincia de Los Ángeles describes it: "The convent was founded in the eastern part of the town, half 
a quarter of a league, next to the bank of a stream in a small or unhealthy valley, at the same time building some principal houses for the Countess" [29]. Madoz also reveals its remoteness from the town: "a quarter of a league from the town" [30].

Given its continuous occupation since its foundation, the monastery has undergone important transformations, of a liturgical and also residential nature, configuring a complex structure of architectures from various periods that currently co-exist, giving response to the needs of the community of Clare Sisters which inhabit them.

In recent years, important conservation work has been carried out, with various projects undertaken, the first in 1998, then 2002 and 2007, by the Cultural Delegation of the Junta de Andalucía, and the latest, in 2014 and 2018, promoted by the same community. In 2019, given the need to continue conservation interventions, a preliminary investigation of the architectural structures and the housing needs of the monastery was proposed as, until then, there had not been any systematic work on the issue.

The reduction in the numbers of the religious community has led to the fact that they are currently inhabiting a part of the monastery that has fewer heritage values, and the most artistic part has been relegated to visits and tourist use. This double reality led us to develop the research included in this article. The fundamental objective of the study was to find a tool that would allow us to obtain variables, which would determine the protection degree of such architecture while, in turn, being compatible with the residential process. (Figure 03 and 04)
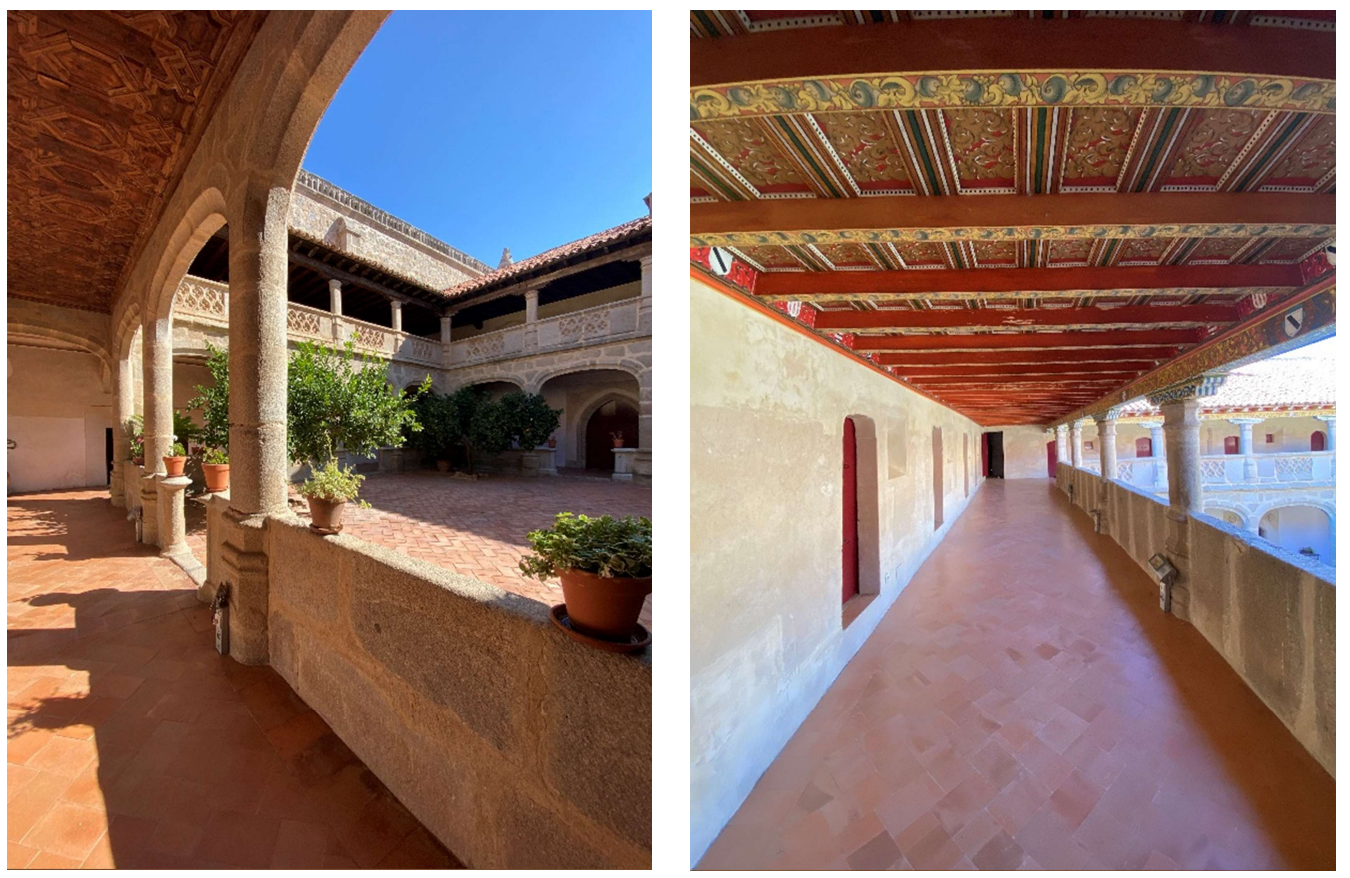

Figure 3 and 4. Photos of the galleries of the monastery cloisters, 2020. Source: Authors.

The dual nature of the studied monastery is not exceptional, and there are numerous protected buildings (palaces, convents, churches, houses, etc.), which are part of this reality. Any inhabited heritage building has the same casuistic and, as a general rule, almost all of them tend to be important heritage pieces. The specific case of monasteries is unique. The decrease in the number of vocations to religious life, together with the toughening of laws and regulations for the conservation of protected architectures, has caused the people who inhabit these unique spaces to retreat to secondary and unprotected areas. This new zoning is due to the fact that it has been chosen to dispense with areas with a wealth of heritage, in exchange for being in secondary spaces, but with options to be adapted to the basic comforts and needs. Something as elementary as the location of a lift, which guarantees accessibility for the elderly, is often not easily manageable within these heritage contexts. 
At present, and due to the complexity of inhabiting a heritage site, the religious community has delimitated a private area, clearly segregated from the public area. (Figure 05) In the private area, the basic questions of living have been reorganized, with a certain quality of life, while in the public area (for tourist visits) no activity can be carried out, due to the restriction of uses. Such segregation prevents actions as obvious as having the meals in the refectory.

What was initially a segregation of uses and routes has ended up being forged into a clearly defined physical separation. It has been from this mirrored reality for a single heritage space, that the objective of this research has arisen, in order to find a tool that can make all these realities converge and coexist in both directions. (Figure 06)

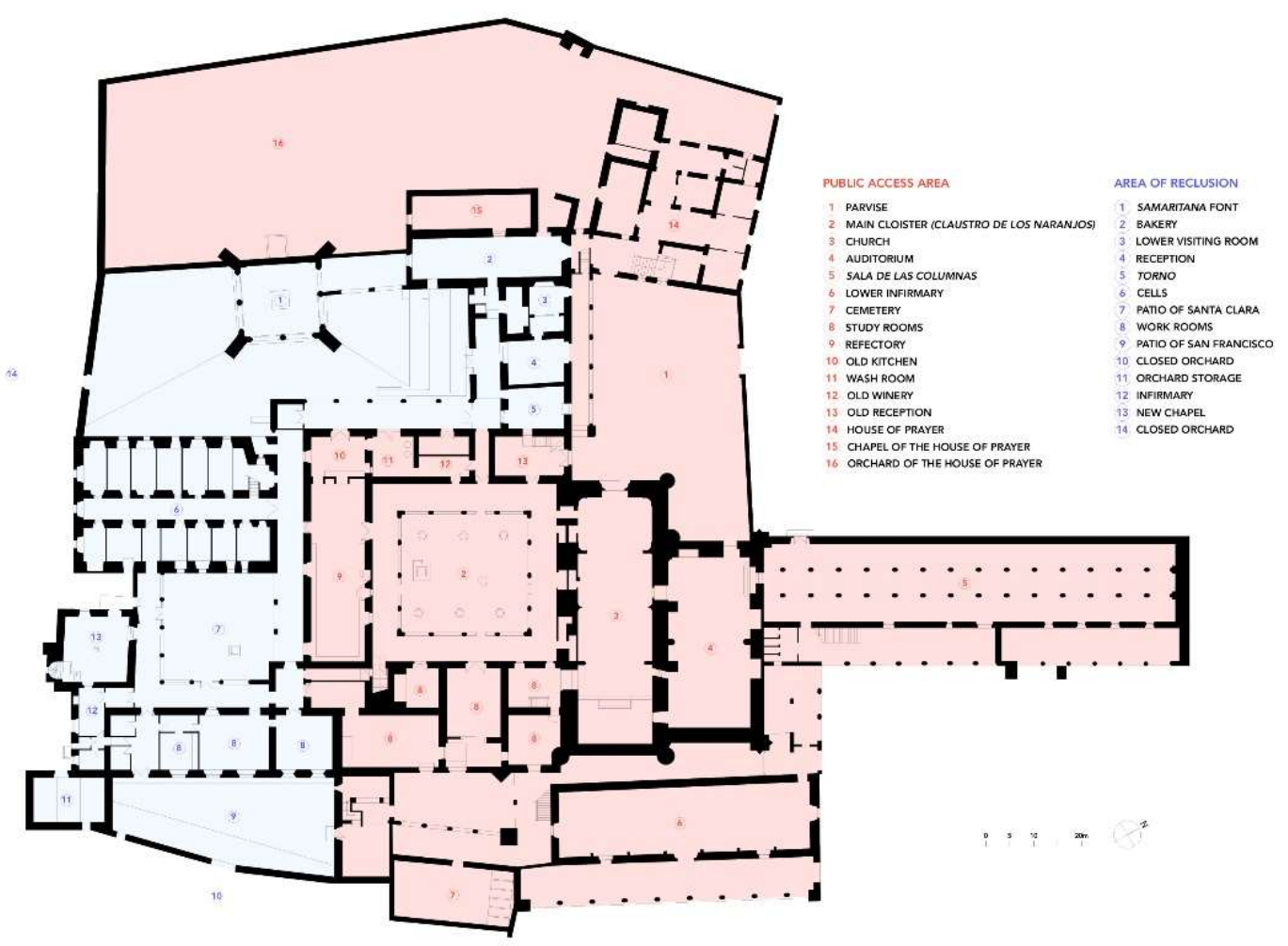

Figure 5. Monastery plan segregated by uses, 2021. Source: Authors.

\section{Discussion}

There are few examples of heritage architectural types still inhabited today in the manner in which they were conceived. Religious architecture is one of these types and, in addition, the monastery combines this double perspective: liturgical use and residential quarters. In relation to the investigation, two processes were developed, taking into account the double objective: the protection and habitability of the monastery. First, an architectural analysis was carried out for the creation of the HBIM model, defining its constructive elements and its heritage qualities, for its parameterization. Its modelling was manual, putting into practice the knowledge acquired, after reflection and ranking of the enclave, according to its qualities. (Figure 07) 
This is why part of the survey process focuses on determining the factors and variables that affect the habitability of the spaces, for their parametric translation, when graphically representing this coexistence within the BIM tool. Thus, we are able to objectify the practice of these two realities: the heritage and the habitable. To this aim, in the second process, and as a conclusion of the study of the potential factors that inform the habitability of the heritage, the following parameters are proposed for the control and measurement of the same, in heritage cases. The aim is to implement what is collected in the research, providing a new perspective to the knowledge of the field of BIM, applied to architectural heritage. Its novel use is made directly into the case study, the Monastery of Santa Clara de la Columna. Although the data, which translate numerically and graphically this reality respond to the detailed parametric definition of the usable building, this production of parameters could be applied to other architectural heritage assets.
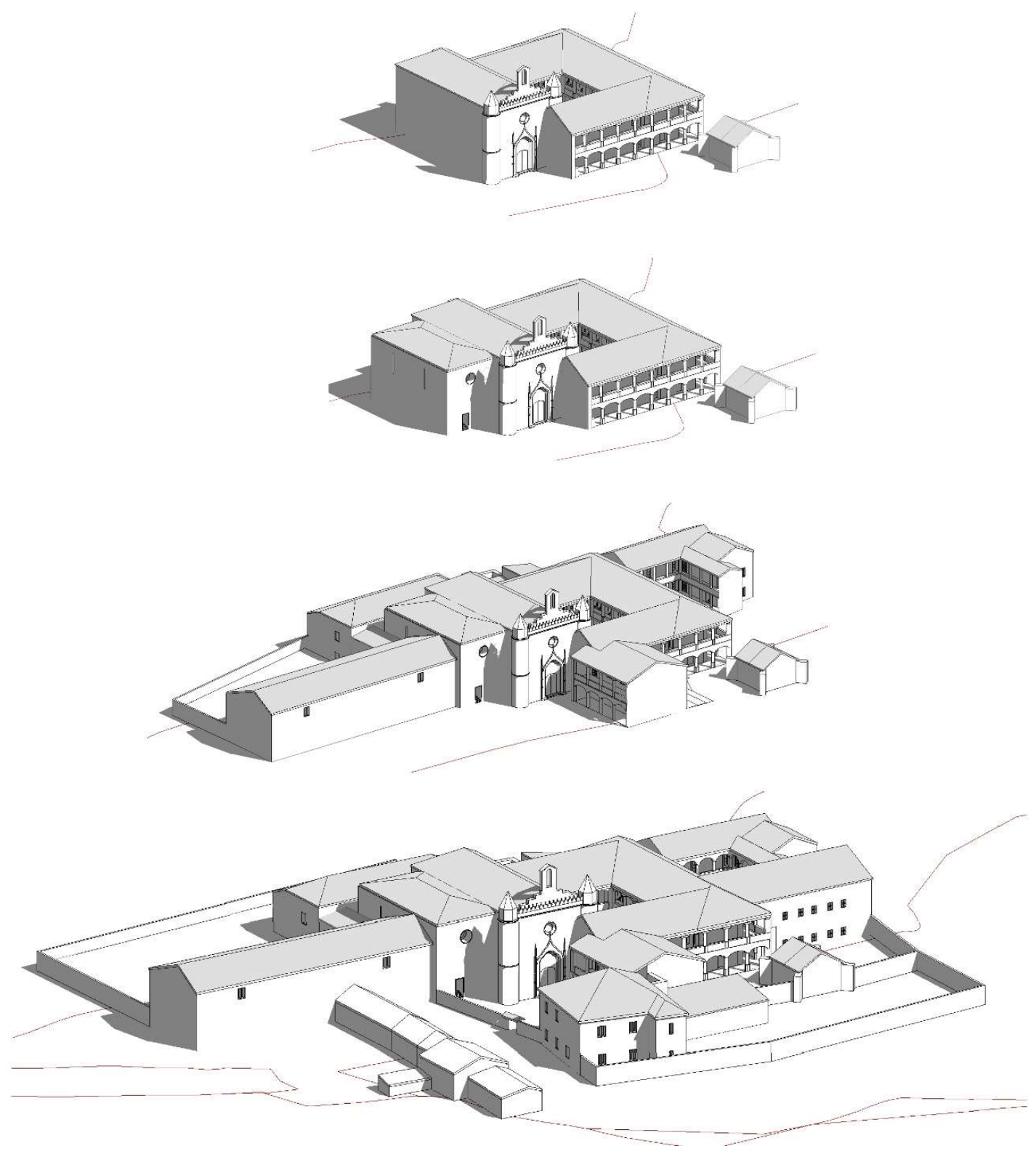

Figure 6. Architectural evolution of the monastic complex, 2021. Source: Authors. 
In order to set comfort standards, by virtue of the habitability concept, the following parameters have been determined, responding to the indications on how to improve the performance of the health systems developed by the World Health Organization. These include the functional provision and adequate development of the physical, social and mental health conditions, safety, hygiene, comfort and privacy [31]. At the same time, the current regulations have been taken into account regarding the requirements of the habitable spaces of the Technical Building Code of Spain, among them we outline: identification, dimension, temperature, acoustics, ventilation, facilities, natural lighting, artificial lighting, accessibility and privacy. The said information is defined in the model, as a result of the study of compliance with the said requirements.

The definition of parameters within the BIM tool, allowed modelling of the basic building structures: walls, floors, roofs, doors, windows, stairs, etc. These elements were programmed with advanced editing options that characterize an unlimited number of contents, as well as an equally unrestricted repertoire of graphic solutions for display. For example, the model includes all the construction systems in its material definition, and its heritage status, regarding interventions, state of conservation, damage, etc. (Figure 08)

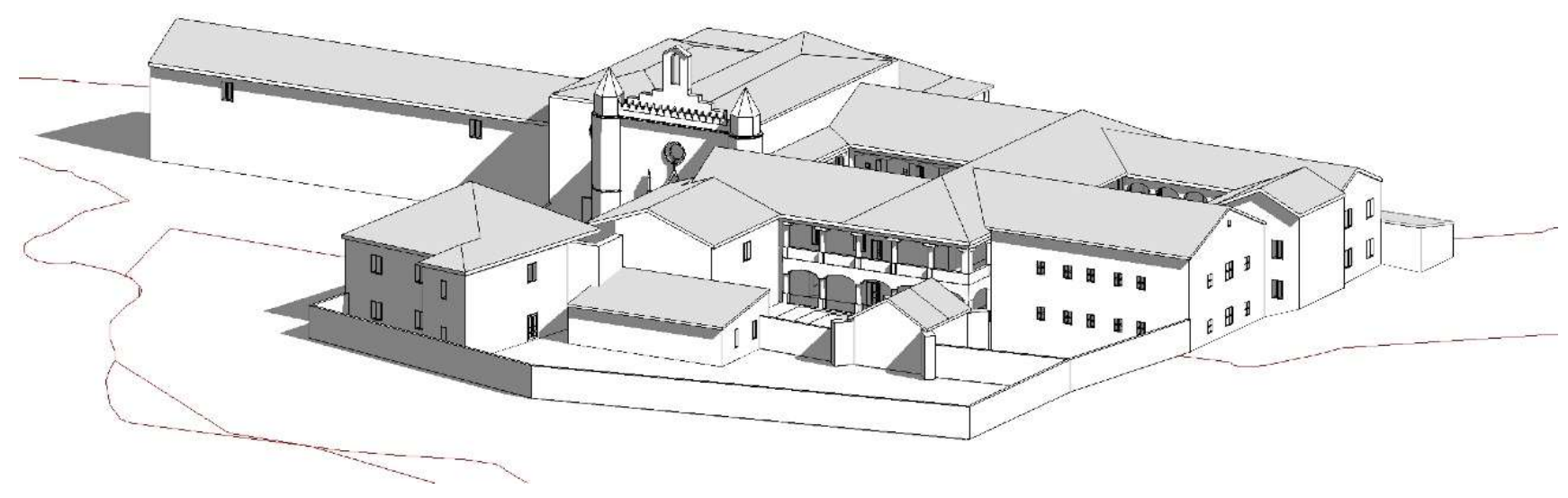

Figure 7. Volumetry of the actual state of the monastery, 2021. Source: the authors.

The precision of this characterization and its progressive use, over time, and based on additions and updates, allows a directly progressive increase in knowledge and reflection on the property. Although the different families, with which it is modelled in the program, offer a series of parameters that can be perfectly compatible with the heritage information in the manner of all construction realities, the tool pemrits the duplication and modification of the existing parameters in its library for the change or addition of information. These have allowed characterization of the historical structures, with respect to qualities, not only geometric, but also in relation to thermal, acoustic, ventilation, etc. This directly affects the behavior of the element, with respect to the spatiality that surrounds it, allowing incorporation and measurement through habitability parameters.

The understanding gained from the physical and social comfort of the inhabitable spaces of the monastery, on which the implementation of these parameters has focused, enables the digital definition to specify a contemporary evaluation of the monastery cells, with respect to their use and domesticity. For this, the spaces associated with the definition parameters collected above, were modelled, and their information was completed, evaluating the benefits that they fulfil or, to the contrary, that lack a positive assessment, regarding habitability. (Figure 09)

In the case of a heritage building, the object parameters of the HBIM model are organized, facilitating their ordering, based on the disciplines which would establish more 
conventional data sets, historical, archaeological, etc., or, according to conventionally recognized areas of protection: identification, research, protection, conservation, dissemination. Within each of these groups, subgroups facilitate the ordering of parameters, with the aim of improving the management of purely multidisciplinary information. In all the structures, the information system can create a semantic data mapping that can be actively applied, and is extractible, in the form of planimetric documentation, reports, tables, etc., using a single data input system. In the current survey, having generated the historical structures characterized with their constructive parameters intrinsic to the BIM, to facilitate the discussion on the convergence of protection and habitability and their heritage parameters, this is added to the definition of the consequent spaces of such volumes, by means of habitability parameters defined as a result of the study of the relationship established by the construction, and its current state. (Figure 10 and Figure 11)

\begin{tabular}{|l|}
\hline Agente y data \\
Autor \\
Data \\
Descripción \\
Estado de conservación \\
Estilo \\
\hline Grado afección \\
\hline Información \\
Intervención \\
Lesión \\
Mantenimiento \\
Nivel Conservación \\
Nivel Protección \\
Nivel Urgencia \\
Nivel Visitabilidad \\
\end{tabular}

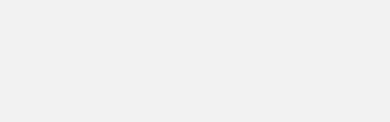

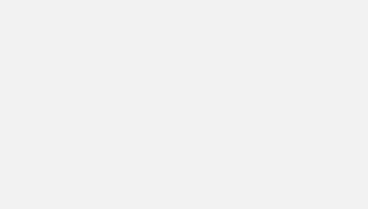

Tipo de parámetro

Parámetro de proyecto

(Puede aparecer en tablas de planificación pero no en etiquetas)

- Parámetro compartido

(Puede compartirse en varios proyectos y familias, exportarse a ODBC y aparecer en tablas de planificación y etiquetas)

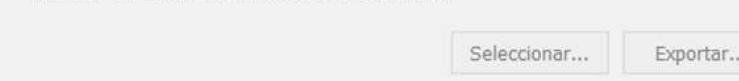

Datos de parámetro

Nombre:

Grado afección

Disciplina:

Común

Tipo de parámetro:

Si/No

Agrupar parámetro en:

Otros

Descripción de información de

< Sin descripción de información de herramientas. Puede editar este parámetro para es...

Editar información de herramientas...

$\checkmark$ Añadir a todos los elementos de las categorías seleccionadas

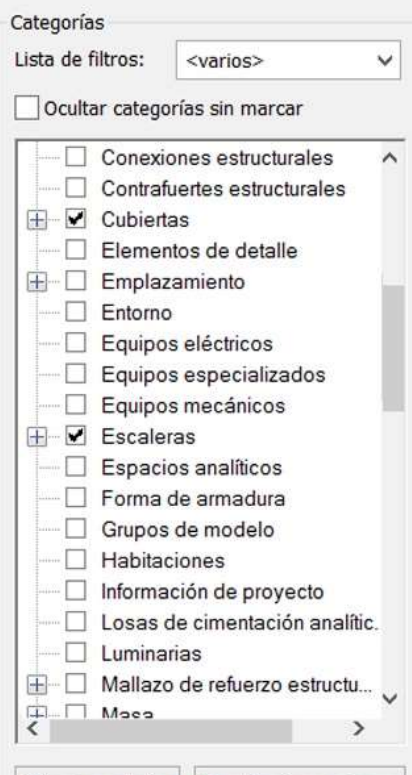

Seleccionar todas No seleccionar ninguna
Cancelar Ayuda

Figure 8. Heritage parameters, 2021.

Within the process of surveying the case study, a structure of parameters, associated with the different elements of the graphic model was designed, allowing the recording of their heritage information. In the deployment of the group of parameters, these are subdivided into elements and spaces enabling the definition of both realities in a parallel manner. This allows the heritage work to be evaluated in a comprehensive manner, not only from the point of view of construction, but also architecturally. This includes aspects intrinsic to the behavior of the property and, therefore, its comprehensive assessment, the objective of the reflection on the contemporaneity of its management. The modelling, therefore, was not only of the volume, but also of the resulting voids, which are ultimately the spaces which make up the architecture. This detailing has been made possible after an analysis of its elements, from their materiality to their construction systems, which has led to the objectification of the definition of the spaces. The incorporation of these parameters has objectified the spatial realities, allowing observation of the performance of the protection within its four bases: identification, protection, conservation and dissemination. The effect is not only to safeguard the knowledge gained from the said heritage, but also to incorporate new visions of housing behavior, gained by contemporary analysis through the use of the BIM tool. In turn, in the case of BIM, all the information collected is available in the form of the properties of the elements and spaces of the model, and, at the same 
time linked in the form of text files and tables, whose modification reverts to the modelling, and vice versa.

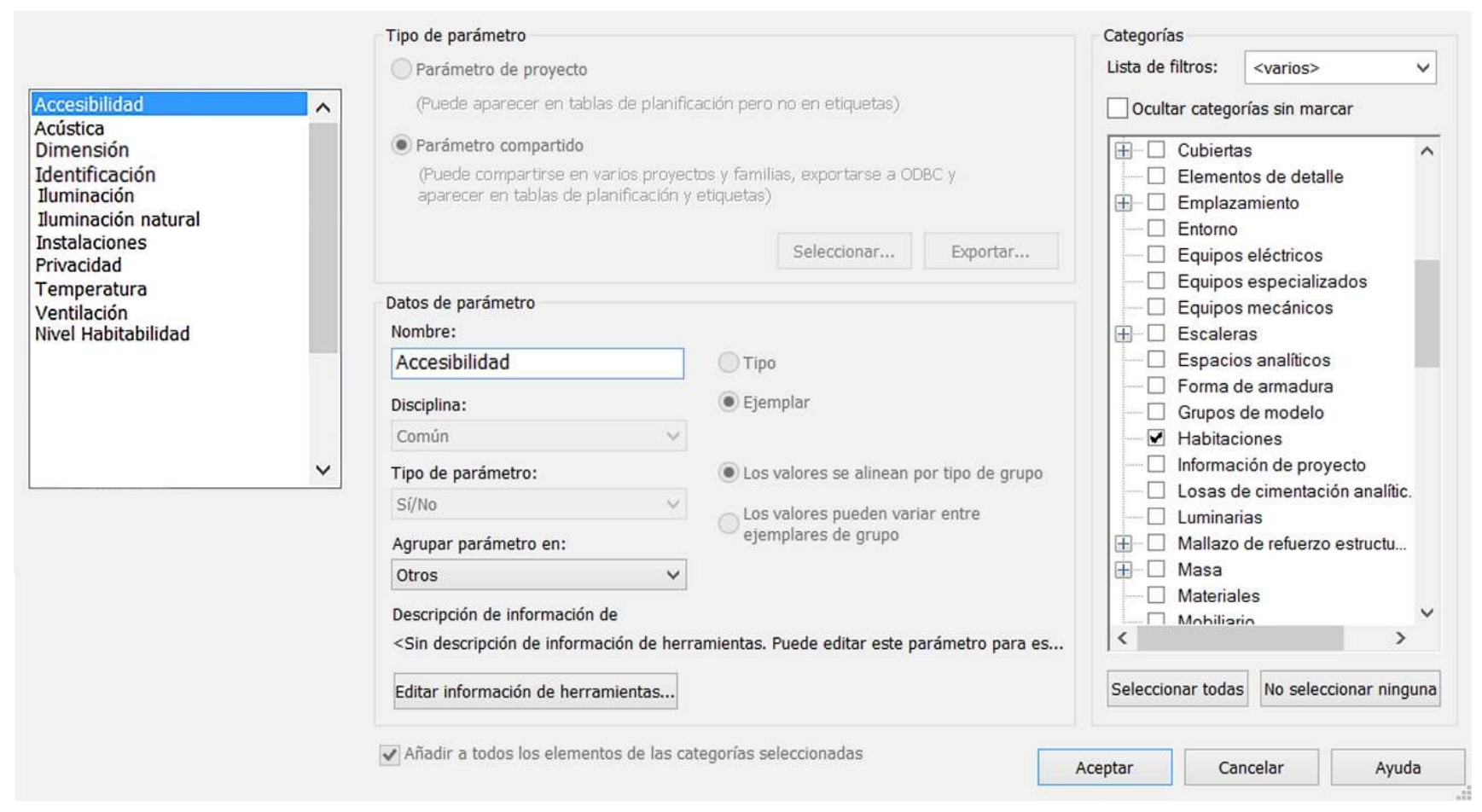

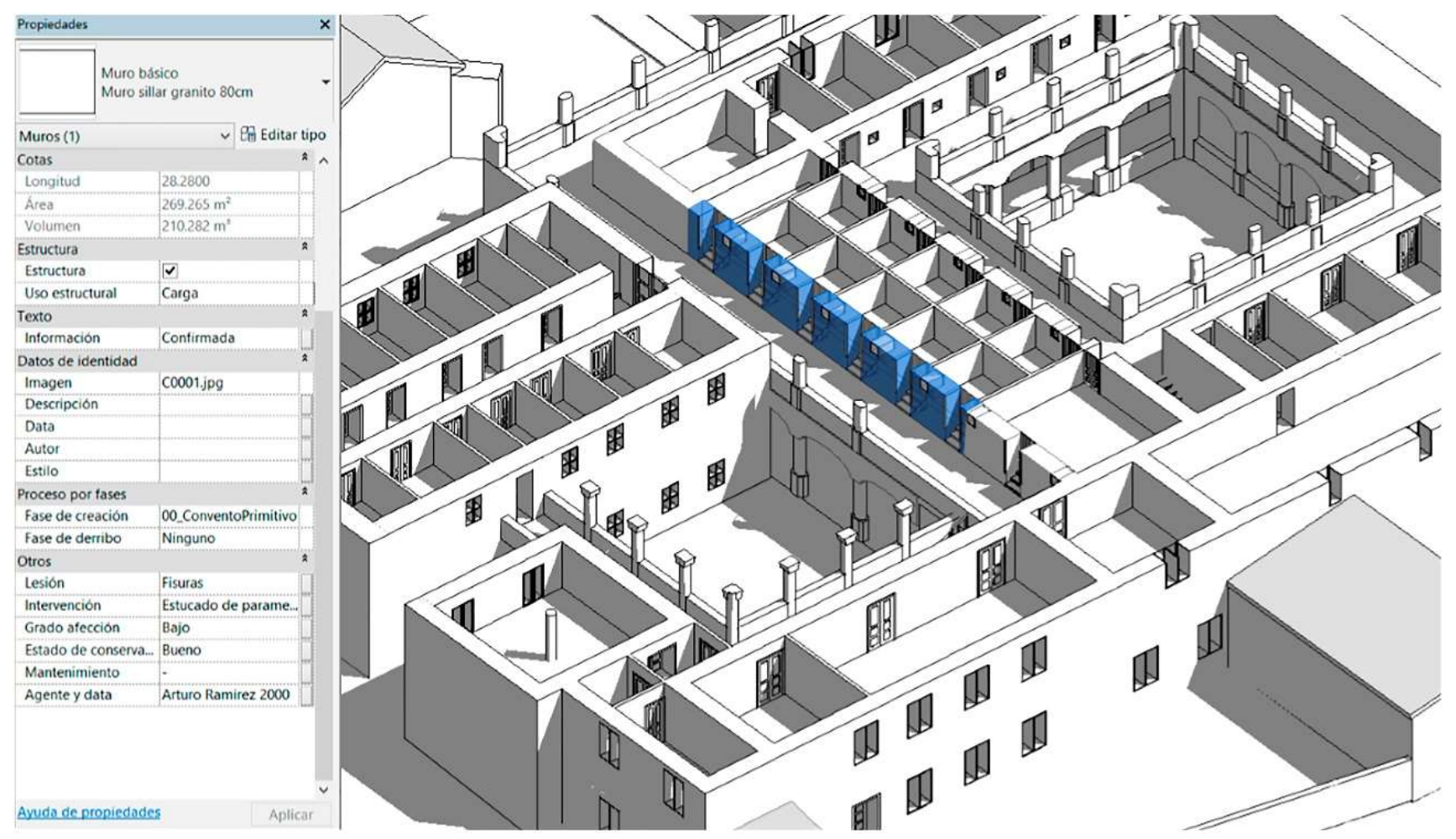

Figure 9. Habitability parameters, 2021.

Figure 10. Study of the walls of the monastery, 2021. 
Creating parameters does not directly enable their visualization. The association and definition of parameters to elements and spaces is reflected in these realities, within their properties, but not in their representation in any of the displays. This is why a display style configuration system has to be modelled, through filters, according to the reflected parameters. Such filters are created according to the relationship that has been established between a parameter and its definition, in such a way that the graphic display style can be created according not only to the parameter, but to its different definitions, facilitating comparison.

As a final result of this process, different floor plans are created which respond to the visualizations achieved, in line with the criteria of the parameters. Its behavior is similar to what would be known as thematic plans, where the graphic representation of the modelled architecture of the buildings appears, and the information that has been transferred and filtered, is indicated with a color legend for easy viewing. (Figure 12)

Through this method, it has been possible to analyze, measure and reflect, both realities in the model in a comprehensive manner, allowing the drawing of comparisons between the spaces. These thematic frames are grouped into views related to the heritage of the spaces, and the synopsis of the habitability factors. The level of protection results from a heritage reading of the current understanding, including custody and the requirements demanded for the formal conservation of the value of the spaces and their level of habitability. These are the result of the factors, intrinsic to the comfort of their inhabitants, provided by the qualities of the elements which constitute the construction systems and the consequent space.
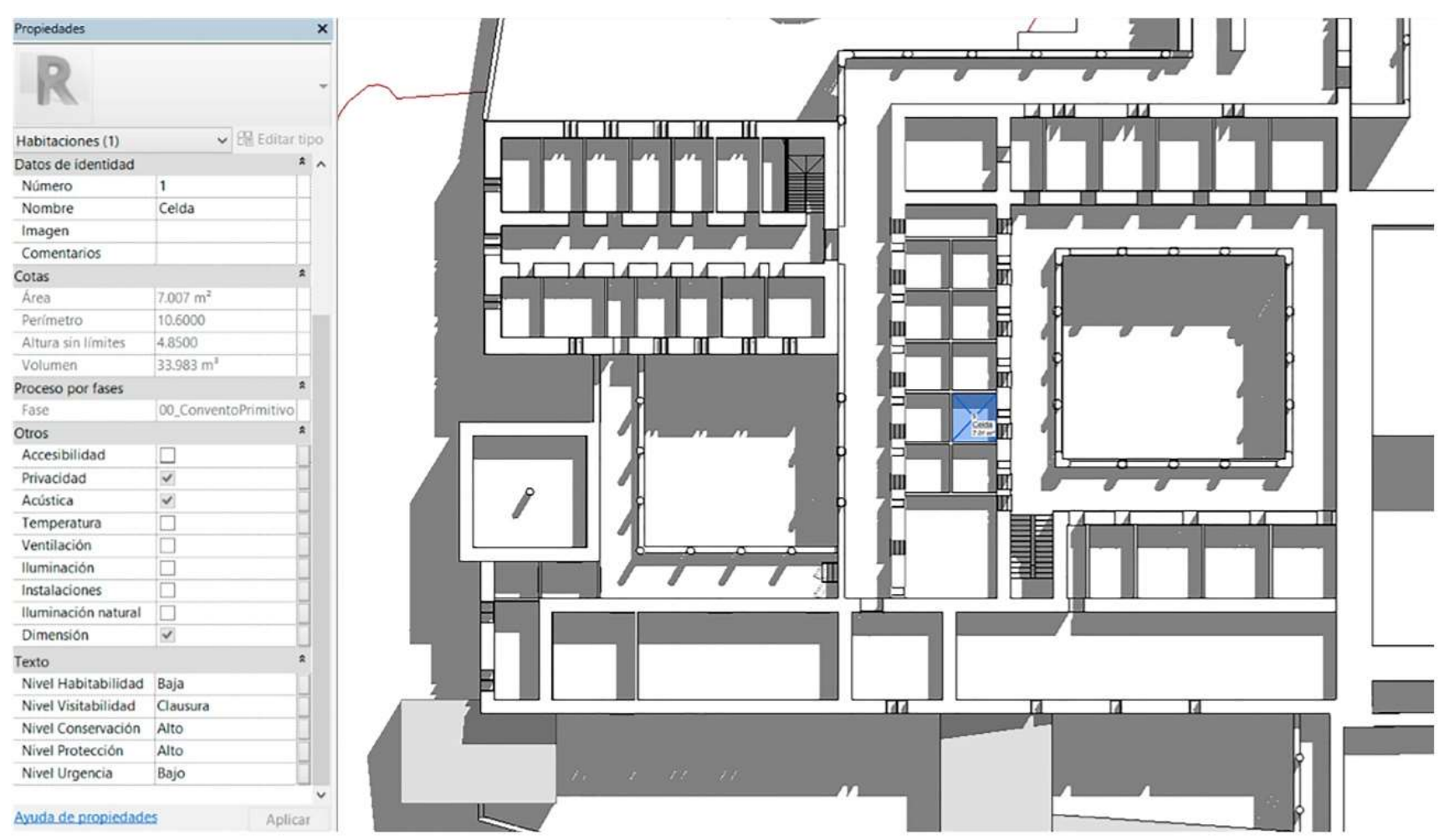

Figure 11. Study of the habitable spaces of the monastic complex, 2021.

\section{Conclusions}

The HBIM model of the Santa Clara de la Columna Monastery, developed with a LOK-300, provides alphanumeric and graphical output, suitable for reflection on the coexistence between heritage and habitat. 
In conclusion, and as a fundamental reason for the development of the survey, the parameterization allows for the advancement of basic three-dimensional graphic modelling. This is achieved through generic elements, and an information structure oriented towards its multidisciplinary analysis and its realities. This is performed in a comprehensive manner, by establishing the general guidelines of its representative planning. Its precision depends precisely on the purpose of the creator of the model, the result being an interactive code, based on common languages of both resources and current intellectual mechanisms, ascribed not only to the conventional graphic representation.

Regarding the protection of spaces, to achieve an analytical and contemporary reflection on habitability, the survey was produced from the detailed definition of physical realities, the materials, construction systems, and their current state, advancing to the assessment of the valuable assets, such as damage and their habitability requirements. The interest in these concepts lies in the fact that they broaden the scope of the evaluation of the quality of the benefits of buildings, in the variety of problems to be considered, and in the scales of analysis and intervention, as well. These allow for the objectification, and therefore the thorough technical and contemporary treatment of this study, for purposes such as research, and the potential intervention or improvement in granting its protection.

The level of habitability, resulting from all the stated evaluation processes, will be a tool to inform the related institutions and agents about the reality of the habitational conditions in relation to the protection. The use of this tool would allow resources to be directed, more efficiently, over the circumstances of each programme, incorporating a more complete and objective perspective of the problems. The main areas of application, within the relevant schedule, are:

1. preliminary evaluation tool, for targeting intervention and maintenance projects.

2. Instruments to establish specific requirements associated with the objectives of each programme, demanding certain compliance with the performance levels.

3. Finally, as a tool for studying and reflecting on domesticity, being a synchronic factor in the historical development of heritage properties.

This third point responds to the initial application of this research, which again affects the contemporary analysis of heritage, from the addition of the habitability factor, to its global vision, in order to promote the transversality and integrity of the acquired knowledge.

The information provided through the implementation of habitability factors, allows for improvement of contemporary sustainability protection as the determining approach to the relationship, in this case, of the nuns with their own spaces. These spaces are neglected in many heritage cases, and adopt a secondary place in favour of protection, so that the qualities related to comfort and health are often subordinated to the conservation and protection of the property. This causes divergence and contradictions, considering the requirements applied to other constructions.

The BIM model, with active parameter management, involves the simplification, at least initially, of the geometry through previous analysis. However, it provides the potential for versatility that this tool offers, allowing for the information to be ordered objectively, according to specific aspects that induce focusing on the survey results

As can be observed, there are two parallel trajectories, in the sense that those spaces with less protection requirements in the relative scale, permit a somewhat looser approach that favours usability. This is why the protection of heritage should not be understood merely as a legal issue, which must be dealt with once the damage has occurred, but it should rather be managed as a preventive strategy to preserve the significant values of the monument for the future.

Such approach to the sustainable development of cultural heritage requires, not only protection against adverse environmental conditions and intentional damage, but also consistent attention to multidisciplinary factors, and the permanent renewal of the per- 
spective of actions. Any approach limited to the formal past, runs the risk of turning heritage into a rigid and frozen entity, which may lose its relevance for the present and desired future of its inhabitants. 


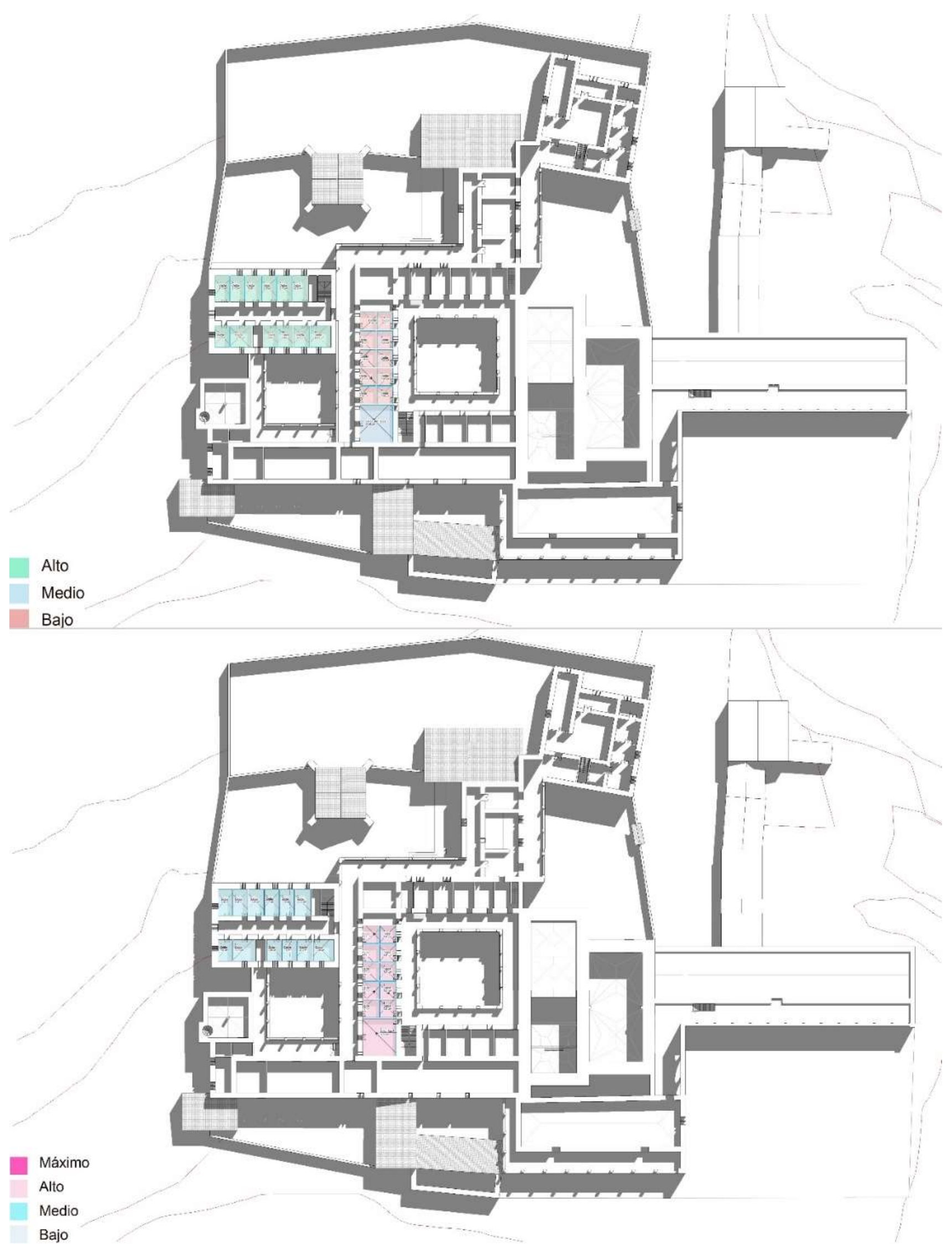

Figure 12. Levels of habitability and patrimonial protection after the study, 2021. 
Funding: The research contained in this article, and its development, has been funded by the VPPIUS of the University of Seville, the Department of Architectural Projects of the University of Seville, the Research Project 4049/1079 FIUS, the Research Foundation of the University of Seville; and, the Asociación Amigos del Monasterio de Santa Clara de la Columna de Belalcázar (Córdoba) (the Friends of the Santa Clara de la Columna de Belalcázar Monastery Association) (Córdoba).

Data Availability Statement: Not applicable.

Acknowledgments: This work has been possible thanks to the generosity of the community of nuns of Santa Clara who live in this monastery. We would like to show them our deepest gratitude. Moreover, we are convinced that the main reason for the survival of the rich heritage of the Monastery of Santa Clara de la Columna endures, is the consistent dedication of the Clare Nuns.

Conflicts of Interest: The authors declare no conflict of interest.

\section{References}

Millán-Millán, P., y Fernández V., L. (2014). Aproximación al estudio de los procesos de transformación de las ciudades históricas. La tematización. Revista EURE - Revista de Estudios Urbano Regionales, 40(120). http://www.eure.cl/index.php/eure/article/view/404

2. De Naeyer, André, Arroyo, S., \& Blanco, J. (2000). Krakow Charter 2000: principles for conservation and restoration of built heritage. Krakow, Polan: Bureau Krakow 2000. http://hdl.handle.net/1854/LU-128776

3. Català Domènech, J. M. (2005). La imagen compleja. La fenomenología de las imágenes en la era de la cultural visual. Servei de Publicacions de la Universitat Autònoma de Barcelona.

4. Jiménez Martín, A., y Pinto Puerto, F. (2003). Levantamiento y análisis de edificios. Tradición y futuro. Universidad de Sevilla. Secretariado de Publicaciones. Instituto Universitario de Ciencias de la Construcción.

5. González Pérez, C. (2018). Modelado de información para arqueología y antropología: principios de ingeniería de software para patrimonio cultural. Createspace Independent Publishing Platform.

6. I.S.O. Standards, 2010.

7. Volk, R., Stengel, J., \& Schultmann F. (2014). Building Information Modelling (BIM) for existing buildings. Literature review and future needs. Automation in Construction, 38, 109-127. https://doi.org/10.1016/j.autcon.2013.10.023

8. Logothetis, S., Delinasiou, A., \& Stylianidis, E. (2015). Building Information Modelling for Cultural Heritage: a Review. International Archives of the Photogrammetry, Remote Sensing and Spatial Information Sciences, II-5/W3, $177-183$. https://doi.org/10.5194/isprsannals-II-5-W3-1772015

9. American Institute of Architects. (2013). AIA Document E-203.

10. Castellano Román, M., \& Pinto Puerto, F. (2019). Dimensions and Levels of Knowledge in Heritage Building Information Modelling, HBIM: The model of the Charterhouse of Jerez (Cádiz, España). Digital Applications in Archeology and Cultural Heritage, 14, 1-11. https://doi.org/10.1016/j. daach.2019.e001

11. Volk, R., Stengel, J., \& Schultmann F. (2014). Building Information Modelling (BIM) for existing buildings. Literature review and future needs. Automation in Construction, 38, 109-127. https://doi.org/10.1016/j.autcon.2013.10.023

12. Edwards, J. (2017). “It's BIM-but not as we know it!”, in Heritage Building Information Modelling. Routledge.

13. Angulo Fornos, R. (2020). Desarrollo de modelos digitales de información como base para el conocimiento, la intervención y la gestión en el patrimonio arquitectónico. De la captura digital al modelo HBIM. [Tesis doctoral, Universidad de Sevilla]. https://idus.us.es/handle/11441/98088

14. Tucci, G., Bonora, V., Conti, A., \& Fiorini, L. (2017). High-quality 3D Models and their Use in a Cultural Heritage Conservation Project. International Archives of the Photogrammetry, Remote Sensing and Spatial Information Sciences, XLII-2/W5, 687-693. https://doi.org/10.5194/isprsarchives-XLII-2-W5-687-2017

15. Angulo Fornos, R. (2020). Desarrollo de modelos digitales de información como base para el conocimiento, la intervención y la gestión en el patrimonio arquitectónico. De la captura digital al modelo HBIM. [Tesis doctoral, Universidad de Sevilla]. https://idus.us.es/handle/11441/98088

16. Apollonio, F. I., Gaiani, M., \& Sun, Z. (2016). A reality integrated BIM for architectural heritage conservation. Handbook of Research on Emerging Technologies for Architectural and Archaeological Heritage, 1(5), 31-65. https://doi.org/10.4018/978-1$\underline{\text { 5225-0675-1.ch002 }}$

17. Castellano Román, M. (2017). La Cartuja de Nuestra Señora de la Defensión en Jerez de la Frontera: un modelo digital de información para la tutela de bienes inmuebles del patrimonio cultural. [Tesis doctoral, Universidad de Sevilla]. https://idus.us.es/handle/11441/65027

18. Garagnani, S. (2013). Building Information Modeling and real world knowledge: A methodological approach to accurate semantic documentation for the built environment. Digital Heritage International Congress (Digital Heritage) 2013, 489-96. https://doi.org/10.1109/DigitalHeritage.2013.6743788

19. Korro Bañuelos, J., Rodríguez Miranda, Á., Valle Melón, J. M., ZornozaIndart, A., Castellano Román, M., Angulo Fornos, R., Pinto Puerto, F., Acosta Ibáñez, P., \& Ferreira Lopes, P. (2021). The Role of Information Management for the Sustainable Conservation of Cultural Heritage. Sustainability, 13(8), 1-21. https://doi.org/10.3390/su13084325 
20. Murphy, M., McGovern, E., \& Pavia, S. (2009). Historic building information modelling (HBIM). Structural Survey, 27(4), 311327. https://doi. org/10.1108/02630800910985108

21. Castellano Román, M., \& Pinto Puerto, F. (2019). Dimensions and Levels of Knowledge in Heritage Building Information Modelling, HBIM: The model of the Charterhouse of Jerez (Cádiz, España). Digital Applications in Archeology and Cultural Heritage, 14, 1-11. https://doi.org/10.1016/j. daach.2019.e001

22. Moreno Pérez, J. R., y García de Casasola Gómez, M. (2017). Patrimonio y habitabilidad contemporánea. PH Instituto Andaluz del Patrimonio Histórico, 9, 120-123. https://doi.org/10.33349/2017.0.3913

23. Rueda, S. (1996). Habitabilidad y calidad de vida. Cuadernos de Investigación Urbanística, 42, $29-33$. https://doi.org/10.1007/s11625-014-0274-4

24. D' Alençon, R., Justiniano, C., Márquez, F., y Valderrama C. (2009). Parámetros y estándares de habitabilidad: calidad en la vivienda, el entorno inmediato y el conjunto habitacional. Universidad Católica de Chile, 9, 271-304. https://doi.org/10.33349/2018.0.4125

25. López, F. J., Lerones, P.M., Llamas, J., Gómez García-Bermejo, J., \& Zalama, E. (2017). A Framework for Using Point Cloud Data of Heritage Buildings Toward Geometry Modeling in A BIM Context: A Case Study on Santa Maria La Real De Mave Church. International Journal of Architectural Heritage, 11(7), 965-986. https://doi.org/10.1080/15583058.2017.1325541

26. Oreni, D., Brumana, R., Della Torre, S., Banfi, F., \& Previtali, M. (2014). Survey turned into HBIM: the restoration and the work involved concerning the Basilica di Collemaggio after the earthquake (L'Aquila). International Archives of the Photogrammetry, Remote Sensing and Spatial Information Sciences, XLII-2/W5, 267-273. https://doi.org/doi:10.3390/su10030908

27. Volk, R., Stengel, J., \& Schultmann F. (2014). Building Information Modelling (BIM) for existing buildings. Literature review and future needs. Automation in Construction, 38, 109-127. https://doi.org/10.1016/j.autcon.2013.10.023

28. Cabrera Muñoz, E. (1977). El condado de Belalcázar (1444-1518). Aportación al estudio del régimen señorial en la Baja Edad Media. Universidad de Córdoba. Córdoba.

29. Crónica de la Provincia Franciscana de Los Ángeles, p. 137.

30. Molinero Merchán, J. A. (2007). El convento de Santa Clara de la Columna de Belalcázar. Diputación Provincial de Córdoba. Córdoba.

31. Organización Mundial de la Salud. (2000). Informe sobre la salud en el mundo 2000. Mejorar el desempeño de los sistemas de salud. Ginebra, Suiza: World Health Report OMS. https://apps.who.int/iris/handle/10665/42357 